\title{
Enhancement of paclitaxel-induced breast cancer cell death via the glycogen synthase kinase-3 $\beta$-mediated B-cell lymphoma 2 regulation
}

\author{
Kyung Tae Noh ${ }^{1, \#, *}$, Gil Sun Cha,", Tae Heung Kang ${ }^{2, \#}$, Joon Cho ${ }^{3, \#}$, In Duk Jung ${ }^{2}$, Kwang-Youn Kim ${ }^{4}$, Soon-Cheol Ahn ${ }^{5}$, \\ Ji Chang You ${ }^{6, *}$ \& Yeong-Min Park ${ }^{2, *}$ \\ ${ }^{1}$ Department of Infectious Diseases, Armed Forces Medical Research Institute, Daejeon 34059, ${ }^{2}$ Department of Immunology, KU Open \\ Innovation Center, College of Medicine, Konkuk University, Chungju 27478, ${ }^{3}$ Department of Neurosurgery, Konkuk University Hospital, \\ Seoul 05030, ${ }^{4}$ School of Life Sciences, Ulsan National Institute of Science and Technology, Ulsan $44919,{ }^{5}$ Department of Microbiology and \\ Immunology, Pusan National University School of Medicine, Yangsan 50612, ${ }^{6}$ National Research Laboratory of Molecular Virology, \\ Department of Pathology, School of Medicine, The Catholic University of Korea, Seoul 03083, Korea
}

Glycogen synthase kinase-3 $\beta$ (GSK-3 $\beta$ ) is a serine/threonine protein kinase that is known to mediate cancer cell death. Here, we show that B-cell lymphoma 2 (Bcl-2), an anti-apoptotic protein, is regulated by GSK-3 $\beta$ and that GSK-3 $\beta$-mediated regulation of $\mathrm{BCl}-2$ is crucial for mitochondrial-dependent cell death in paclitaxel-stimulated cells. We demonstrate that MCF7 GSK$3 \beta$ siRNA cells are more sensitive to cell death than MCF7 GFP

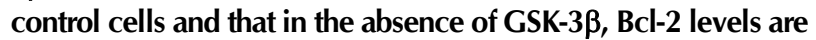
reduced, a result enhanced by paclitaxel. Paclitaxel-induced JNK (c-Jun N-terminal kinase) activation is critical for $\mathrm{Bcl}-2$ modulation. In the absence of GSK-3 $\beta, \mathrm{Bcl}-2$ was unstable in an ubiquitination-dependent manner in both basal- and paclitaxeltreated cells. Furthermore, we demonstrate that GSK-3 $\beta$-mediated regulation of $\mathrm{Bcl}-2$ influences cytochrome $\mathrm{C}$ release and mitochondrial membrane potential. Taken together, our data suggest that GSK-3 $\beta$-dependent regulation of $\mathrm{Bcl}-2$ is crucial for mitochondria-dependent cell death in paclitaxel-mediated breast cancer therapy. [BMB Reports 2016; 49(1): 51-56]

\section{INTRODUCTION}

Glycogen synthase kinase-3 (GSK-3), a serine/threonine protein

*Corresponding authors. Yeong-Min Park, Tel: +82-2-2049-6158; Fax: +82-2-2049-6192; E-mail: immun3023@kku.ac.kr, Kyung Tae Noh, Tel: +82-2-2049-6158; Fax: +82-2-2049-6192; E-mail: nkt2062@ hanmail.net, Ji Chang You, Tel: +82-2-2258-7312; Fax: +82-22258-7790; E-mail: jiyou@catholic.ac.kr

${ }^{\#}$ These authors contributed equally to this work.

http://dx.doi.org/10.5483/BMBRep.2016.49.1.102

Received 22 May 2015, Revised 16 June 2015, Accepted 5 August 2015

Keywords: B-cell lymphoma 2, Breast cancer, Cell death, Glycogen synthase kinase-3 $\beta$, Paclitaxel kinase, is involved in various cellular processes; it was first identified as an important regulator of glycogen synthesis (1). GSK-3 has two isoforms, GSK-3 $\alpha$ and GSK-3 $\beta$ (2), and two phosphorylatable residues, Ser9 and Tyr216, whose phosphorylation determines the activity of GSK-3 $\beta$ (3). Whereas GSK-3 $\beta$ activation generally requires phosphorylation on Tyr216; the Ser9 residue is critical for inhibition of activity $(2,3)$. GSK-3 $\beta$ is involved in multiple physiological responses such as cell survival, apoptosis, metabolism, diabetes, and homeostasis (2-7). In detail, knockout studies of GSK-3 $\beta$ have shown that it is crucial for Nuclear factor $\kappa B$ (NFKB-dependent cell survival (7); Ser9 phosphorylation of GSK-3 $\beta$ promotes cell survival via cAMP response element binding protein (CREB)-dependent $\mathrm{BCl}-2$ expression (8). Phosphorylation of Tyr216 in GSK-3 $\beta$ regulates p53, which enhances Bax expression, resulting in cell death (9). GSK-3 $\beta$-mediated phosphorylation of Bax promotes its mitochondrial localization, thus initiates neuronal apoptosis (10).

Apoptosis is crucial for recovery of damaged and infected cells (11); this mechanism is triggered through two signaling pathways, the intrinsic and extrinsic pathways $(12,13)$. The intrinsic mitochondrial pathway is initiated when pro-apoptotic signals from outside the cell are transmitted within the cell (12, 13). This pathway hinges on the balance of activity between anti-and pro-apoptotic signals of the Bcl-2 family $(14,15)$. In the normal state, $\mathrm{Bcl}-2$ combines with pro-apoptotic proteins (Bid, Bim, Bax, and Bak) and locates to the mitochondria. When an apoptotic signal from the outside is transmitted, the level of $\mathrm{Bcl}-2$ is reduced, pro-apoptotic proteins combine with each other, the mitochondrial structure is changed, and apoptosis is initiated $(14,15)$. The extrinsic pathway occurs outside the cell through activation of pro-apoptotic receptors on the surface (6). Both pathways contribute to the activation of intracellular cysteine proteases, referred to as caspases $(6,14,15)$.

Paclitaxel is a well known and effective medicine for tumor chemotherapy; it is widely used against a broad range of cancers including breast, lung, and ovarian cancers (16, 17).

ISSN: 1976-670X (electronic edition)

Copyright (c) 2016 by the The Korean Society for Biochemistry and Molecular Biology

(c) This is an open-access article distributed under the terms of the Creative Commons Attribution Non-Commercial License (http://creativecommons.org/licenses/by-nc/4.0) which permits unrestricted non-commercial use, distribution, and reproduction in any medium, provided the original work is properly cited. 
Paclitaxel functions as a mitotic inhibitor, targeting microtubules $(18,19)$. Rodi et al. demonstrated that Bcl-2 was a target of paclitaxel by screening a library of phage-displayed peptides (20).

Here, we demonstrate the absence of GSK-3 $\beta$ enhanced breast cancer cell death induced by paclitaxel. We also demonstrate that paclitaxel-induced breast cancer cell death occurs through the intrinsic apoptosis pathway and is dependent on GSK-3 $\beta$ regulation of $\mathrm{Bcl}-2$, using a GSK-3 $\beta$ siRNA system.

\section{RESULTS}

\section{Paclitaxel-induced cell death is greater in MCF7 GSK-3 $\beta$ siRNA cells than in MCF7 GFP control cells}

In a previous report, we found that the level of apoptosis-signal regulating kinase 1 (ASK1) was regulated by GSK-3 $\beta$ (21). Thus, we investigated whether the presence of GSK-3 $\beta$ influences cell death in paclitaxel-stimulated conditions, using MCF7 GSK-3 $\beta$ siRNA cells. First, we examined the cell death population change in MCF7 GFP control and MCF7 GSK-3 $\beta$ siRNA cells by paclitaxel stimulation, using Annexin V/propidium iodide (PI) staining. We observed that the population of Annexin V-stained cells in paclitaxel-treated MCF7 GSK-3 $\beta$ siRNA cells was greater than in paclitaxel-treated MCF7 GFP control cells (Fig. 1A). We confirmed this observation using the TUNEL assay, showing a large increase in paclitaxel-induced TUNEL-positive nuclei in the absence of GSK-3 $\beta$ (Fig. 1C). Furthermore, in a DNA fragmentation assay, paclitaxel treatment resulted in greater DNA fragmentation in GSK-3 $\beta$ knockdown cells (Fig. 1B) than in controls. From these results, we concluded that paclitaxel-induced breast cancer cell death was increased in GSK-3 $\beta$ knockdown cells.

A

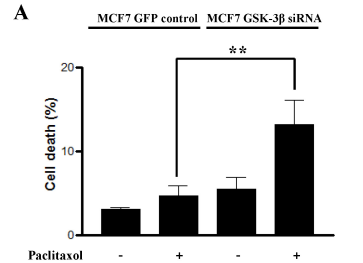

C
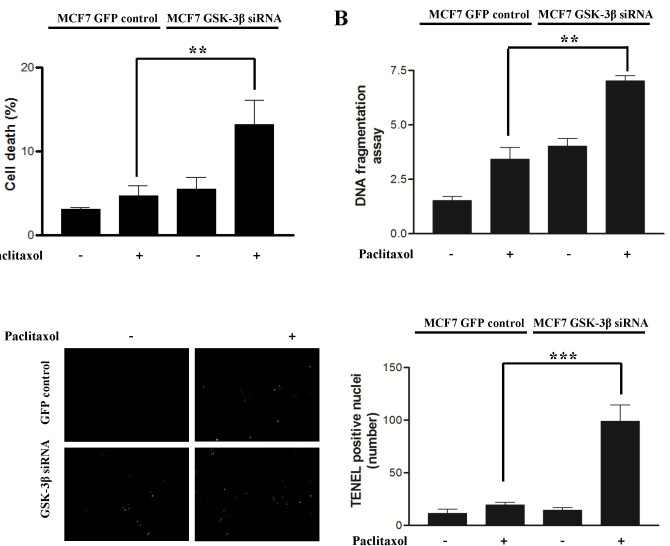

Fig. 1. Paclitaxel-mediated cell death is sensitive in MCF7 GSK-3 $\beta$ siRNA cell, compared to in MCF7 GFP control cell. MCF7 GFP control and MCF7 GSK-3 $\beta$ siRNA group were treated with paclitaxel (2 $\mu \mathrm{M})$ for $18 \mathrm{~h}$. And then, cells were harvested and subjected to following assay, (A) using the Annexin $\mathrm{V},(\mathrm{B})$ the DNA fragmentation, and, $(C)$ the TUNEL assay, to check cell death. The mean \pm SEM values shown represent three independent experiments. $* * \mathrm{P}<$ $0.01 ; * * P<0.001$.
Paclitaxel-induced $\mathrm{Bcl}-2$ decrease is greater in the absence of GSK-3 $\beta$ and JNK activity is crucial for paclitaxel-induced reduction of $\mathrm{BCl}-2$

The $\mathrm{BCl}-2$ family of proteins is known as mediators of cell death, and an interaction between GSK-3 $\beta$ and Bcl-2 family proteins has been previously reported $(8,10)$. Because of the GSK-3 $\beta$-dependent differences in cell death observed, we examined the level of the anti-apoptotic protein $\mathrm{Bcl}-2$ in MCF7 GFP control and MCF7 GSK-3 $\beta$ siRNA cells. Fig. 2A shows that, in the absence of GSK-3 $\beta, \mathrm{BCl}-2$ levels are diminished; this is also the case with paclitaxel-induced decrease of Bcl-2 in GSK-3 3 knockdown cells (Fig. 2A). These results were confirmed by confocal microscopy (Fig. 2B). In addition, we investigated paclitaxel-induced activation of MAPKs (JNK and p38) and found that paclitaxel-induced activation of these MAPKs is greater in MCF7 GSK-3 $\beta$ siRNA cells than in MCF7 GFP control cells (Fig. 2C). Furthermore, we found that JNK activity is critical for paclitaxel-mediated Bcl-2 modulation (Fig. 2D). From these results, we deduced that GSK-3 $\beta$ regulates $\mathrm{Bcl}-2$ levels in both basal and paclitaxel-treated cells, and that JNK activity is crucial for paclitaxel-induced reduction of $\mathrm{Bcl}-2$.

Bcl-2 stability is reduced in the GSK-3 $\beta$ knockdown condition In previous experiments, we found that GSK-3 $\beta$ regulates the level of Bcl-2 in paclitaxel-treated cells. Here, we performed
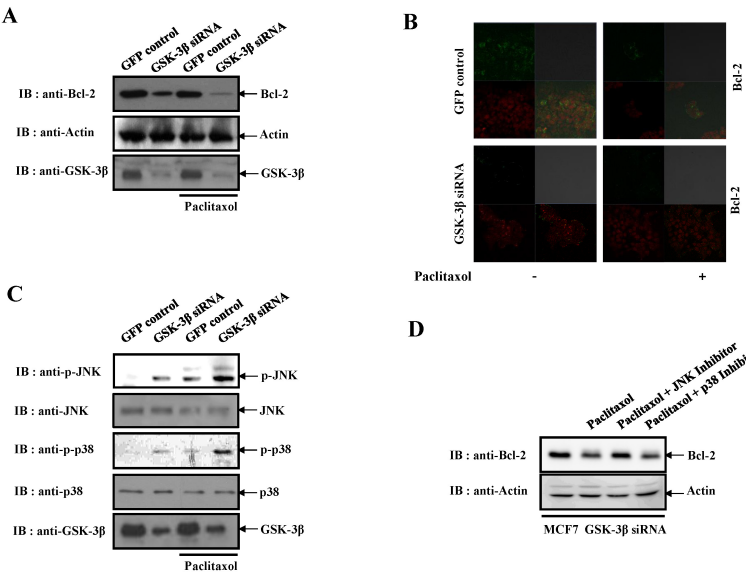

D

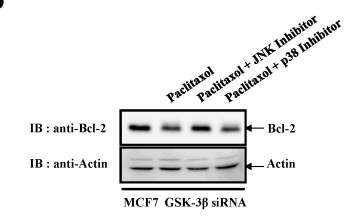

Fig. 2. Paclitaxel-induced decrease of $\mathrm{Bcl}-2$ expression is sensitive in GSK-3 $\beta$ knockdown condition, JNK activity is crucial for paclitaxelinduced reduction of Bcl-2. MCF7 GFP control and MCF7 GSK-3 $\beta$ siRNA cells were incubated with paclitaxel $(2 \mu \mathrm{M})$ for $2 \mathrm{~s}$. (A) Cells were harvested and immunoblotted with Bcl-2, Actin, and GSK-3 $\beta$ antibody. (B) Cells were fixed, permeablized, and stained with FITCconjugated Bcl-2 antibody, and then stained with TO-PRO-3. (C) Cells were incubated with paclitaxel $(2 \mu \mathrm{M})$ for $30 \mathrm{~min}$, and harvested cells were subjected to immunnoblotting against p-JNK, JNK, p-p38, and, p38. (D) MCF7 GSK-3 $\beta$ siRNA cells were pre-treated with JNK inhibitor, SB600125 (25 $\mu \mathrm{M})$ or p38 inhibitor, SB203580 $(10 \mu \mathrm{M})$ for $30 \mathrm{~min}$, and then cells were treated with paclitaxel $(2 \mu \mathrm{M})$ for $2 \mathrm{~h}$. Cells were harvested and immunoblotted with Bcl- 2 and Actin. The results are representative of three independent experiments. 
time course experiments to examine the stability of Bcl-2. As shown in Fig. $3 \mathrm{~A}, \mathrm{Bcl}-2$ is stable in the presence of GSK-3 $\beta$ during paclitaxel stimulation. However, in the absence of GSK-3 $\beta$, paclitaxel treatment resulted in decreased levels of $\mathrm{BCl}-2$ levels (Fig. 3A). Therefore, we investigated whether GSK$3 \beta$ influenced the turnover rate of $\mathrm{BCl}-2$ in the presence of paclitaxel using cycloheximide $(\mathrm{CHX})$. We found that $\mathrm{Bcl}-2$ is more stable in paclitaxel-treated cells in the presence of GSK$3 \beta$, suggesting GSK-3 $\beta$-mediated $\mathrm{BCl}-2$ stabilization is resistant to proteosomal degradation (Fig. 3B). These results showed that GSK-3 $\beta$ plays a pivotal role in $\mathrm{Bcl}-2$ stability under basal and paclitaxel-stimulated conditions. Most proteins degraded by the proteasome are dependent on ubiquitination (22). Due to the aberrant paclitaxel-mediated proteasomal degradation of $\mathrm{BCl}-2$ in the absence of GSK-3 $\beta$, we examined the effect of GSK-3 3 on the ubiquitination of $\mathrm{BCl}-2$. Consistent with previous stability data, in the absence or inhibition of GSK-3 $\beta$, more ubiquitinated $\mathrm{Bcl}-2$ was observed than in the presence of GSK-3 $\beta$ (Fig. 3C, D). In addition, we observed paclitaxel-mediated activation of GSK-3 $\beta$ via phosphorylations of Ser9 and Tyr216 residues (Fig. 3E). Furthermore, in paclitaxel-treated cells, a much stronger ubiquitination of $\mathrm{Bcl}-2$ was detected in cells with GSK-3 $\beta$ knockdown compared to control cells (Fig. 3F). Therefore, we concluded that GSK-3 $\beta$ activity is crucial for
Bcl-2 ubiquitination under basal and paclitaxel-treated conditions.

\section{Paclitaxel-induced/stimulated/triggered cytochrome C release and mitochondrial membrane potential collapse are greater in MCF7 GSK-3 $\beta$ siRNA cells compared to MCF7 GFP control cells}

Cytochrome $\mathrm{C}$ is an intermediate in apoptosis, a regulated form of cell death used to kill cells in response to infection, in the process of development, or DNA damage (23). In previous results, we found paclitaxel-induced cell death and aberrant $\mathrm{BCl}-2$ reduction in the absence of GSK-3 $\beta$. Therefore, we investigated paclitaxel-induced cytochrome $\mathrm{C}$ release and mitochondrial membrane potential in the presence or absence of GSK-3 $\beta$. MCF7 GFP control and MCF7 GSK-3 $\beta$ siRNA cells were treated with paclitaxel $(2 \mu \mathrm{M})$, incubated for 18 hours, and then harvested. Cytosolic and mitochondrial fraction assays using digitonin were performed. As shown in Fig. 4A, more cytochrome $C$ release in the presence of paclitaxel was observed in MCF7 GSK-3 $\beta$ siRNA cells compared to MCF7 GFP control cells. Mitochondrial membrane potential is an important barrier of apoptosis via cytochrome $C$ release (24). Thus, we investigated whether paclitaxel treatment in the presence or absence GSK-3 $\beta$ affects the biochemical structure of mito-
A

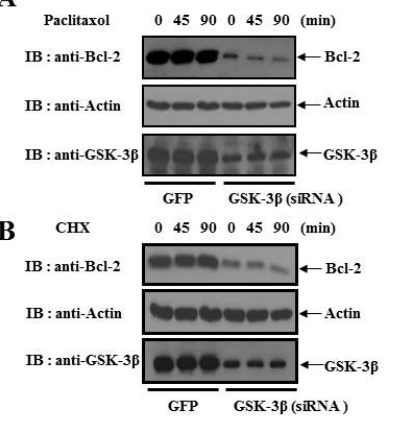

C

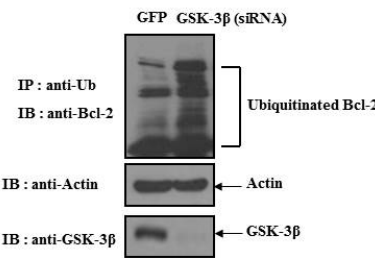

D

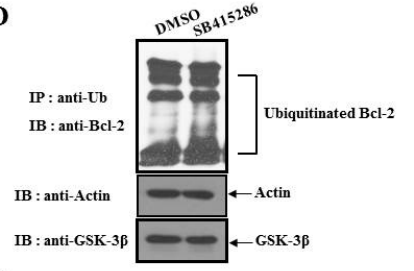

E

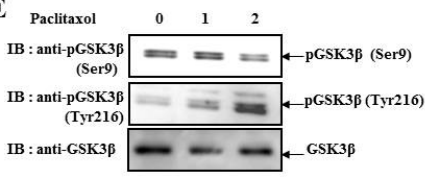

$\mathbf{F}$

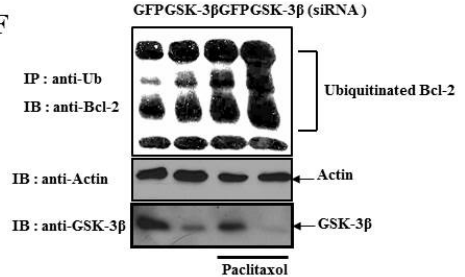

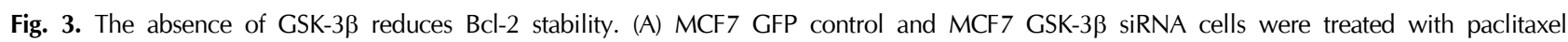
$(2 \mu \mathrm{M})$ for 45 and $90 \mathrm{~min}$. (B) MCF7 GFP control and MCF7 GSK-3 3 siRNA cells were exposed to cylcloheximide $(100 \mu \mathrm{g} / \mathrm{ml})$ for the indicated times, and then cells were harvested and immunoblotted with indicated antibodies. The results are representative of three independent experiments. (C) MCF7 GFP control and MCF7 GSK-3 $\beta$ siRNA cells were harvested and immunoblotted with indicated antibodies. (D) MCF7 cells were treated with GSK-3 3 inhibitor, SB415286 $(25 \mu \mathrm{M})$, for $30 \mathrm{~min}$. Cells were harvested and performed immunoblot assay with BCl-2 antibodies. (E) MCF7 GFP control and MCF7 GSK-3 $\beta$ siRNA cells were incubated with indicated doses of paclitaxel for 30 min. Cells were harvested and subjected to immunnoblotting against GSK-3 $\beta$ (Ser9) and GSK-3 $\beta$ (Tyr216) antibody. (F) MCF7 GFP control and MCF7 GSK-3 $\beta$ siRNA cells were pretreated with proteasome inhibitor, MG132 $(10 \mu \mathrm{M})$, and then incubated with paclitaxel $(2 \mu \mathrm{M})$ for $4 \mathrm{~h}$. Bcl-2 ubiquitination was determined by immnoprecipitation with anti-Ub followed by immnoblotting with anti-Bcl-2. The results are representative of three independent experiments. 
A

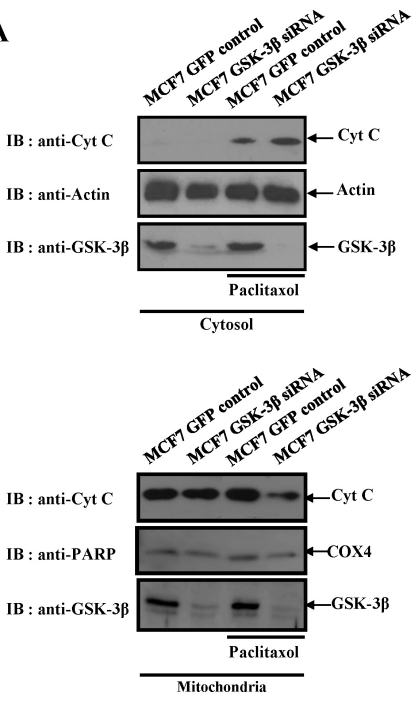

B

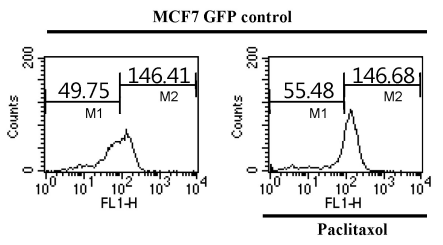

MCF7 GSK-3ß siRNA

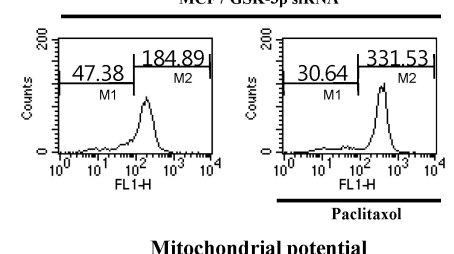

Fig. 4. Paclitaxel-induced cytochrome $C$ release and mitochondrial potential collapse are significant in MCF7 GSK- $3 \beta$ siRNA cell, compared to those in MCF7 GFP control cell. MCF7 GFP control and MCF7 GSK3 $\beta$ siRNA cells were treated paclitaxel $(2 \mu \mathrm{M})$ for $18 \mathrm{~h}$. (A) Cells were fractionated with mitochondrial and cytosolic fractions. Each fraction was subjected to immunoblotted with indicated antibodies. (B) MCF7 GFP control and MCF7 GSK3 $\beta$ siRNA cells were treated paclitaxel $(2 \mu \mathrm{M})$ for $18 \mathrm{~h}$, and then cells were harvested and stained with $\mathrm{DiOC}_{6}(3)$. The fluorescence activity of $\mathrm{DiOC}_{6}(3)$ was determined by flow cytometory. The results are representative of three independent experiments. chondria. Paclitaxel-induced mitochondrial membrane potential collapse was greater in the absence of GSK-3 $\beta$ than in the presence of GSK-3 $\beta$ (Fig. 4B). From these results, we concluded that GSK-3 $\beta$ functions as a barrier to cytochrome $C$ release and mitochondrial membrane potential collapse in paclitaxel-stimulated cells.

\section{DISCUSSION}

In this work, we studied the synergistic effect of paclitaxel and GSK-3 $\beta$ siRNA in MCF7 breast cancer cells. GSK-3 $\beta$ functions as an important regulator of cell death induced by various stresses (6). Bcl-2 family members can be classified into three subfamilies based on functional and structural features (11), this family of proteins is localized to smooth endoplasmic reticulum and mitochondria and functions as anti-apoptotic proteins.

Interaction between GSK-3 $\beta$ and the $\mathrm{Bcl}-2$ family proteins has been reported. GSK-3 $\beta$ exhibits pro-apoptotic effects by modulating Bax, a pro-apoptotic protein (10). GSK-3 $\beta$ inhibition evokes cell survival via CREB-dependent-Bcl-2 expression (8). In recent, it was reported that interleukin 17A inhibits au-

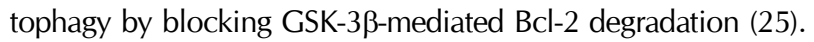
However, under conditions of paclitaxel treatment, the relationship between GSK-3 $\beta$ and $\mathrm{BCl}-2$ has not been addressed. Here, we investigated this question based on our previous results demonstrating that the level of apoptosis-signal regulating kinase 1 (ASK1) is regulated by GSK-3ß (21). In addition, our and other group have been investigating on the relevance between GSK3 beta and MAPKs (21, 26-28).

Paclitaxel is a drug widely used in chemotherapy; it is a microtubule-targeting agent that is effective against a wide range of cancers (29). Paclitaxel-treated cells have defects in mitotic spindle assembly, chromosome isolation, and cell division (16, 18, 30). In previous studies, Rodi et al. demonstrated that
Bcl-2 was also a target of paclitaxel (20), a finding verified by demonstrating that the structure of $\mathrm{Bcl}-2$ is similar to that of $\beta$-tubulin (31). In this study, we showed that $\mathrm{BCl}-2$ could be an indirect target of paclitaxel via GSK-3 $\beta$.

Saunders et al. (32) first showed that paclitaxel could be an inducer of breast cancer cell death, and other works demonstrated synergistic effects between paclitaxel and other anti-tumor drugs in enhancing breast cancer cell death (33). In this study, we demonstrate an alternative mechanism to enhance the effects of paclitaxel on MCF7 breast cancer cells. We observed that paclitaxel was more effective in killing breast cancer cells in the absence of GSK-3 $\beta$, using various cell death assays including Annexin V/propidium iodide (PI) staining, DNA fragmentation assay, and TUNEL assay. We also monitored BCl-2 expression in paclitaxel-treated MCF7 GFP control and MCF7 GSK-3 $\beta$ siRNA cells and found that GSK-3 $\beta$ affected $\mathrm{BCl}-2$ levels in basal and paclitaxel-treated condition. In GSK-3 $\beta$ knockdown cells, Bcl-2 levels were reduced compared with control cells. Bcl-2 levels were further reduced in paclitaxel-treated MCF7 GSK-3 $\beta$ siRNA cells compared with paclitaxel-treated MCF7 GFP control cells. We also showed that JNK activity is important for paclitaxel-mediated $\mathrm{Bcl}-2$ modulation. Furthermore, we observed that $\mathrm{Bcl}-2$ stability is dependent on GSK-3 $\beta$ in the presence of paclitaxel and that GSK-3 $\beta$-mediated $\mathrm{Bcl}-2$ stability is via ubiquitination pathway in basal and paclitaxel-stimulated conditions. Because Bcl-2 levels are crucial for cytochrome $C$ release, we investigated the effect of GSK-3 $\beta$ on cytochrome $C$ release and mitochondria membrane potential collapse under conditions of paclitaxel treatment. From the series of experiments, we concluded that GSK-3 $\beta$ absence-mediated $\mathrm{Bcl}-2$ reduction causes hyper-sensitive cell death of breast cancer by paclitaxol.

In future studies, we plan to define the detailed mechanism of GSK-3 $\beta$ inhibition-mediated $\mathrm{Bcl}-2$ reduction and, to use this 
information for therapeutic benefit to treat breast and other cancers using nano-particle and GSK-3 $\beta$ siRNA. This work should provide both better understanding and increased effectiveness of combined therapy using a GSK3 inhibitor and paclitaxel to accelerate the development of effective breast cancer drugs.

\section{MATERIALS AND METHODS}

\section{Cell culture}

MCF7 GFP control and MCF GSK-3 $\beta$ siRNA cells were kindly provided by Dr. Eui-ju Choi (Korea university, South Korea). Cells were maintained in Dulbecco's modified Eagle's medium (DMEM) (Invitrogen, Carlsbad, CA) supplemented with 10\% fetal bovine serum, penicillin $(100 \mathrm{U} / \mathrm{ml})$, and streptomycin (100 $\mu \mathrm{g} / \mathrm{ml}$ ) under a humidified atmosphere of $5 \% \mathrm{CO}_{2}$ at $37^{\circ} \mathrm{C}$.

\section{Reagents and antibodies}

Antibodies against Bcl-2, Actin, GSK-3 $\beta$, cytochrome C, and COX4 were purchased from Santa Cruz Biotechnology (Santa Cruz, CA). The anti-pJNK, anti-JNK, anti-pp38, and anti-p38 were obtained from Cell Signaling Technology Inc. (Beverly, MA). Paclitaxol was purchased from Tocris Bioscience (Bristol, UK). DiOC6(3) was purchased from Enzo Life Sciences (Farmingdale, NY). Annexin V-FITC Apoptosis Detection Kit (BD Biosciences, Lexington, KY), TUNEL Assay Kit (Thermo Scientific, Waltham, MA), and Subcellular Protein Fractionation Kit (Thermo Scientific, Waltham, MA) were used.

\section{Detection of apoptosis}

MCF7 GFP control and MCF GSK-3 $\beta$ siRNA cells $\left(1 \times 10^{5}\right.$ cells) were were trypsinized, incubated with annexin V-FITC and propidium iodide $(\mathrm{PI})$, and analysed by flow cytometry (FACSCalibur, BD Biosciences) with CellQuest software (BD Biosciences, Lexington, KY) for the detection of apoptotic cells (annexin V-positive, PI-negative). Abovementioned cells were also incubated with TUNEL reaction mixture for apoptosis analysis and then stained with DAPI. TUNEL-positive nuclei were analysed for apoptosis under analyzed by fluorescent microscope (Carl Zeiss Axiovert 200 fluorescence microscope, Germany). Data were expressed as the percentages of TUNELpositive nuclei (the number of TUNEL-positive nuclei/the number of DAPI-stained nuclei $\times 100$ ). DNA fragmentation was studied, using Cell Death Detection ELISA plus, as described by the manufacturer (Roche Diagnostics, Indianapolis, IN).

\section{Western immunoblot analysis}

Western bolt analysis was performed as previously described (34). In brief, cell lysates were subjected to SDS-PAGE and transferred to PVDF membranes. The PVDF membranes were then blocked with $5 \%$ nonfat milk in a washing buffer $(50 \mathrm{~mm}$ Tris- $\mathrm{HCl}, \mathrm{pH} 8.0,150 \mathrm{~mm} \mathrm{NaCl}, 0.1 \%$ Tween 20) and incubated with the indicated antibodies for $1 \mathrm{~h}$ at room temperature. The membranes were washed and incubated for $1 \mathrm{~h}$ at room temperature with the appropriate secondary antibodies conjugated with horseradish peroxidase (Thermo Scientific, Waltham, MA). Protein bands were visualized using an enhanced chemiluminescence system (Thermo Scientific, Waltham, MA).

\section{Subcellular fractionation}

Briefly, MCF7 GFP control and MCF GSK-3 $\beta$ siRNA cells were harvested and trypsinized. The supernatant were removed and incubated with digitonin buffer $\left(10 \mathrm{mM}\right.$ piperazine- $\mathrm{N}, \mathrm{N}^{\prime}$-bis (ethanesulfonic acid) (PIPES), $\mathrm{pH} 6.8,0.015 \% \mathrm{e} / \mathrm{v}$ digitonin, $300 \mathrm{mM}$ sucrose, $100 \mathrm{mM} \mathrm{NaCl}, 3 \mathrm{mM} \mathrm{MgCl} 2,5 \mathrm{mM}$ EDTA, Protease inhibitor (Bio Basic Inc, Canada)) in the ice for $3 \mathrm{~min}$, and then centrifuged $3 \times 10^{3} \mathrm{rpm}$ for $10 \mathrm{~min}$. The supernatant is cytosolic fraction and pellet is mitochondrial fraction.

\section{Confocal laser scanning microscopy}

MCF7 GFP control and MCF GSK-3 $\beta$ siRNA cells were seeded in the six-well plates for $24 \mathrm{~h}$, and treated with paclitaxel for $18 \mathrm{~h}$. Cells were fixed in $4 \%$ formaldehyde for $15 \mathrm{~min}$, and permeabilized with $0.1 \%$ Triton X-100 for 7 min. Next, cells were blocked with PBS containing $5 \%$ bovine serum albumin for $1 \mathrm{~h}$ and subjected to immunofluorescent staining with mouse anti-Bcl-2 polyclonal antibody for a further $2 \mathrm{~h}$ at room temperature or overnight at $4^{\circ} \mathrm{C}$, and then followed by Alexa Fluor 488 anti-mouse IgG $(\mathrm{H}+\mathrm{L})$ (Invitrogen, Carlsbad, $\mathrm{CA})$ for $1 \mathrm{~h}$ at room temperature. Finally, fluorescence signals were analyzed by confocal laser scanning microscope (LSM710, Carl Zeiss, Germany).

\section{Assessment of $\Delta \Psi \mathrm{m}$}

$\Delta \Psi \mathrm{m}$ was assessed by measuring retention of the lipophilic cationic dye $\mathrm{DiOC}_{6}(3)$ in mitochondria. Cells were harvested and incubated in $\mathrm{a} \mathrm{DiOC}_{6}(3)$ solution (20 $\mathrm{nM}$ in fresh medium) for $30 \mathrm{~min}$ at $37^{\circ} \mathrm{C}$ in the dark. The cells were then washed and resuspended in PBS. Immediately after PBS washing, $\triangle \Psi m$ was measured by sorting the cells using FACSCalibur BD Biosciences, Lexington, KY). Dead cells were excluded by forward and side-scatter gating. Data were acquired by analyzing an average population of $1 \times 10^{4}$ cells using CELLQuest software BD Biosciences, Lexington, $\mathrm{KY}$ ).

\section{Statistical analysis}

All experiments were repeated at least 3 times with consistent results. Unless otherwise stated, data were expressed as the mean \pm SEM. Analysis of variance was used to compare experimental groups with control values, while comparisons between multiple groups were made using Tukey's multiple comparison tests (Prism 3.0 GraphPad software). A P value less than 0.05 was considered to indicate statistical significance.

\section{ACKNOWLEDGEMENTS}

This research was supported by Basic Science Research Program through the National Research Foundation of Korea 
(NRF) funded by the Ministry of Education, Science and Technology (2012R1A1A2042924, 2012R1A2A1A03008433, and 2013R1A2A2A01068353)

\section{REFERENCES}

1. Embi N, Rylatt DB and Cohen P (1980) Glycogen synthase kinase-3 from rabbit skeletal muscle. Separation from cyclic-AMP-dependent protein kinase and phosphorylase kinase. Eur J Biochem 107, 519-527

2. Jope RS and Johnson GV (2004) The glamour and gloom of glycogen synthase kinase-3. Trends Biochem Sci 29, 95-102

3. Doble BW and Woodgett JR (2003) GSK-3: tricks of the trade for a multi-tasking kinase. J Cell Sci 116(Pt 7), 1175-1186

4. Shin J, Yu SB, Yu UY, Jo SA, Ahn JH (2010) Swedish mutation within amyloid precursor protein modulates global gene expression towards the pathogenesis of Alzheimer's disease. BMB Rep 43, 704-709

5. Xiong Q, Deng CY, Chai J (2009) Knockdown of endogenous SKIP gene enhanced insulin-induced glycogen synthesis signaling in differentiating C2C12 myoblasts. BMB Rep 42, 119-124

6. Beurel E and Jope RS (2006) The paradoxical pro- and anti-apoptotic actions of GSK3 in the intrinsic and extrinsic apoptosis signaling pathways. Prog Neurobiol 79, 173-189

7. Hoeflich KP, Luo J, Rubie EA, Tsao MS, Jin O, Woodgett JR (2000) Requirement for glycogen synthase kinase-3beta in cell survival and NF-kappaB activation. Nature 406, 86-90

8. Belkhiri A, Dar AA, Zaika A, Kelley M, El-Rifai W (2008) t-Darpp promotes cancer cell survival by up-regulation of $\mathrm{Bcl} 2$ through Akt-dependent mechanism. Cancer Res 68, 395-403

9. Tan J, Zhuang L, Leong HS, Iyer NG, Liu ET, Yu Q (2005) Pharmacologic modulation of glycogen synthase kinase-3beta promotes p53-dependent apoptosis through a direct Bax-mediated mitochondrial pathway in colorectal cancer cells. Cancer Res 65, 9012-9020

10. Linseman DA, Butts BD, Precht TA et al (2004) Glycogen synthase kinase-3beta phosphorylates Bax and promotes its mitochondrial localization during neuronal apoptosis. J Neurosci 24, 9993-10002

11. Willis S, Day CL, Hinds MG, Huang DC (2003) The Bcl-2-regulated apoptotic pathway. J Cell Sci 116(Pt 20), 4053-4056

12. Kang $\mathrm{MH}$ and Reynolds $\mathrm{CP}$ (2009) Bcl-2 inhibitors: targeting mitochondrial apoptotic pathways in cancer therapy. Clin Cancer Res 15, 1126-1132

13. Kroemer G (1999) Mitochondrial control of apoptosis: an overview. Biochem Soc Symp 66, 1-15

14. Letai A, Bassik MC, Walensky LD, Sorcinelli MD, Weiler S, Korsmeyer SJ (2002) Distinct BH3 domains either sensitize or activate mitochondrial apoptosis, serving as prototype cancer therapeutics. Cancer Cell 2, 183-192

15. Wang K, Yin XM, Chao DT, Milliman CL, Korsmeyer SJ (1996) BID: a novel BH3 domain-only death agonist. Genes Dev 10, 2859-2869

16. Rowinsky EK (1997) The development and clinical utility of the taxane class of antimicrotubule chemotherapy agents. Annu Rev Med 48, 353-374

17. Slichenmyer WJ and Von Hoff DD (1991) Taxol: a new and ef- fective anti-cancer drug. Anticancer Drugs 2, 519-530

18. Horwitz SB (1992) Mechanism of action of taxol. Trends Pharmacol Sci 13, 134-136

19. Schiff PB and Horwitz SB (1980) Taxol stabilizes microtubules in mouse fibroblast cells. Proc Natl Acad Sci U S A 77, 1561-1565

20. Rodi DJ, Janes RW, Sanganee HJ, Holton RA, Wallace BA, Makowski L (1999) Screening of a library of phage-displayed peptides identifies human bcl-2 as a taxol-binding protein. J Mol Biol 285, 197-203

21. Noh KT, Park YM, Cho SG, Choi EJ (2011) GSK-3beta-induced ASK1 stabilization is crucial in LPS-induced endotoxin shock. Exp Cell Res 317, 1663-1668

22. Ciechanover A (1994) The ubiquitin-proteasome proteolytic pathway. Cell 79, 13-21

23. Liu X, Kim CN, Yang J, Jemmerson R, Wang X (1996) Induction of apoptotic program in cell- free extracts: requirement for dATP and cytochrome c. Cell 86, 147-157

24. Henry-Mowatt J, Dive C, Martinou JC, James D (2004) Role of mitochondrial membrane permeabilization in apoptosis and cancer. Oncogene 23, 2850-2860

25. Liu H, Mi S, Li Z, Hua F, Hu ZW (2013) Interleukin 17A inhibits autophagy through activation of PIK3CA to interrupt the GSK3B-mediated degradation of BCL2 in lung epithelial cells. Autophagy 9, 730-742

26. Noh KT, Son KH, Jung ID (2012) Protein kinase C delta (PKCdelta)-extracellular signal-regulated kinase 1/2 (ERK1/2) signaling cascade regulates glycogen synthase kinase-3 (GSK-3) inhibition- mediated interleukin-10 (IL-10) expression in lipopolysaccharide (LPS)-induced endotoxemia. J Biol Chem 287, 14226-14233

27. Kim JW, Lee JE, Kim MJ, Cho EG, Cho SG, Choi EJ (2003) Glycogen synthase kinase 3 beta is a natural activator of mitogen-activated protein kinase/extracellular signal-regulated kinase kinase kinase 1 (MEKK1). J Biol Chem 278, 13995-14001

28. Wang Q, Zhou Y, Wang X, Evers BM (2006) Glycogen synthase kinase-3 is a negative regulator of extracellular signal-regulated kinase. Oncogene 25, 43-50

29. Yvon AM, Wadsworth $P$ and Jordan MA (1999) Taxol suppresses dynamics of individual microtubules in living human tumor cells. Mol Biol Cell 10, 947-959

30. Tange S, Scherer MN, Graeb C (2002) The antineoplastic drug Paclitaxel has immunosuppressive properties that can effectively promote allograft survival in a rat heart transplant model. Transplantation 73, 216-223

31. Amos LA and Lowe J (1999) How Taxol stabilises microtubule structure. Chem Biol 6, R65-69

32. Saunders DE, Lawrence WD, Christensen C, Wappler NL, Ruan H, Deppe G (1997) Paclitaxel-induced apoptosis in MCF-7 breast-cancer cells. Int J Cancer 70, 214-220

33. Liu K, Cang S, Ma Y, Chiao JW (2013) Synergistic effect of paclitaxel and epigenetic agent phenethyl isothiocyanate on growth inhibition, cell cycle arrest and apoptosis in breast cancer cells. Cancer Cell Int 13, 10

34. Lee SJ, Noh KT2, Kang TH (2014) The Mycobacterium avium subsp. Paratuberculosis protein MAP1305 modulates dendritic cell-mediated T cell proliferation through Toll-like receptor-4. BMB Rep 47, 115-120 